\title{
BULGARIAN WOODEN CALENDARS
}

\section{Vesselina Koleva}

\begin{abstract}
The article presents a short review of the characteristic features of Bulgarian wooden calendars. Particular attention has been paid to the structure of calendar records and special signs marking the fixed feast days throughout the year in the Orthodox liturgical calendar. A group of calendar sticks from the central part of the Rhodope Mountains, repeatedly used during the 19th century, illustrate this little known folk tradition. Parallels are drawn with wooden calendars from other countries.
\end{abstract}

Key words: calendar stick, fixed feasts, Orthodox Church calendar, rabosh, wooden calendar

\section{THE WOODEN CALENDAR TRADITION}

Calendars made of wood, bone or other materials are a specific form of timekeeping devices. In the Middle Ages, in the areas where the population was converted to Christianity they were a convenient way of establishing the Christian chronology and the liturgical calendar of the Western or Eastern Church. In Eurasia and North America such calendars were in use until the beginning of the 20 th century along with the hand-written and printed ones. There are several museum collections in the world where tens and hundreds of them have been kept until now.

As of the 16th century many Western writers began to include in their works data about such calendars. They also explain one of the most important calculations in the Middle Ages - the date of Easter in the Christian calendar. The most elaborate type of Scandinavian runic calendars exhibits (besides the dominical letters and the fixed feast-day signs) 19 additional characters in order to define the Sundays and the dates of the moveable feasts in different years of the luni-solar cycle.

In the second half of the 19th century the first publications about wooden calendars in Russia and a significant review about Northern wooden calendars were published (Sreznevskii 1876). We get some idea about the presence of calendar sticks on the Balkans from the works of Milovan Gavazzi (1938) and Günter Stipa (1966). The writers refer to some ethnographic publications from 
the end of the 19th and the first half of the 20th century that report about scanty finds in Bulgaria, Bosnia and Herzegovina, Croatia, Albania, Slovenia and the Banat region in Central Europe.

The first study of a calendar stick from Bulgaria was carried out by Stoian Argirov (1896). The object came from Haskovo region and was registered in the collection of the National Library and Museum in Plovdiv in 1883. Additional information on this and other calendars was published by Dimitar Marinov (1907; 1914). Later other ethnographic works appeared about objects from Kyustendil (Zakhariev 1929), Burgas (Vakarelski 1936; Gorov 1997) and Smolyan (Detev 1947) regions. Unfortunately, none of these calendars has survived until now. New objects from the Central Rhodope Mountains (Smolyan region) were described at the times of ethnographic expeditions in the 1970s and 1990s (Koleva 1967; 1971).

While examining the cultural environment of Zyryan wooden calendars (Komi Republic, Russia), Stipa pays attention to the fact that two calendars from the Olib Island (Croatia) with the Western feast system (Gavazzi 1938) and one from the village of Vizinga (Komi) with the Orthodox feast system (Lipin 2006) are similar in their appearance to some Bulgarian calendars. The fact that a calendar stick found in Akhtopol (Bulgaria) was brought as a gift from Mount Athos to its owner living then in Tsiknihor (now in Turkey) (Vakarelski 1936) is also of considerable importance to Stipa. He refers to similar information found in a manuscript from the St Gallen monastery (now in Switzerland) according to which in around $900 \mathrm{CE}$ notched sticks were used as a calendar (Stipa 1966: 205). Logically, he concludes that the spreading of this form of timekeeping among the Finno-Ugric peoples could follow the steps of the Christianity - from Greece and Bulgaria to Central and North Russia.

\section{CHARACTERISTIC FEATURES OF BULGARIAN WOODEN CALENDARS}

Bulgarian Christians used calendar sticks until the beginning of the 20th century. At present, about twenty objects are preserved in museum collections and some others are in private possession. Most numerous is the group from the Central Rhodopes (Smolyan region) and there are a few samples from the regions of Kyustendil, Haskovo, and Burgas (see Fig. 1).

We suppose it is not by chance that all of the calendars have been found in the southern periphery of the country. In these upland areas being a shepherd was a widespread occupation, and it was exactly the shepherds who needed a precise and weatherproof calendar when they were away from home. The sticks 


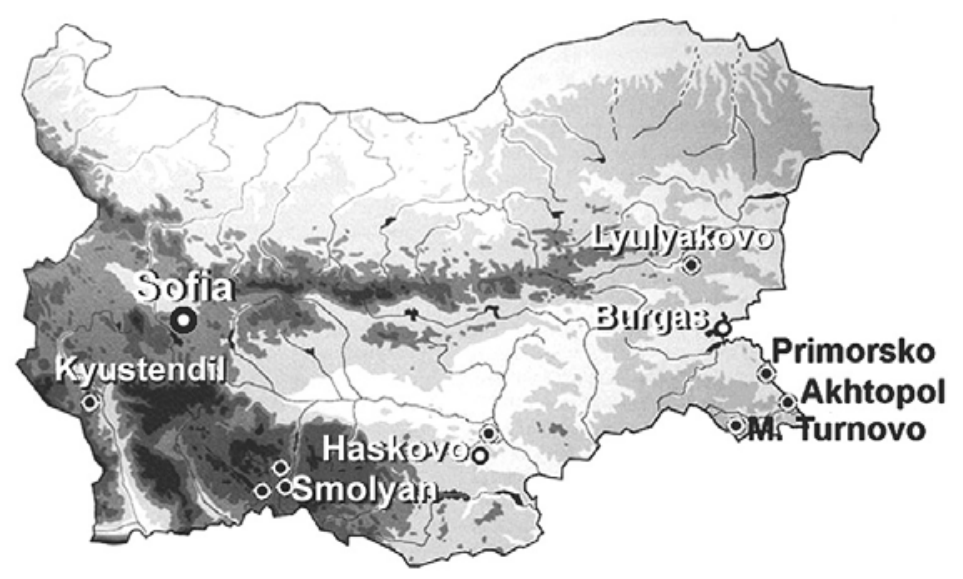

Figure 1. Distribution of wooden calendars in Bulgaria.

successfully substituted the hand-written and printed calendars. They were also a more reliable way to preserve the Christian calendar until 1912 when these areas were liberated from the Ottoman rule. This is also proved by the four calendars from the Burgas region which belonged to Bulgarian Christians from Eastern Thrace and Asia Minor, who were forced to move after the RussoTurkish War of 1877-1878, and the Bucharest peace treaty of 1913 (Koleva \& Georgiev 2006; Koleva 2007).

According to Dimitar Marinov (1907) the Bulgarian wooden calendars were meant to serve both economic and religious needs (Fig. 2). They were mainly in possession of priests and shepherds, and their heirs kept the wooden sticks as a family relic.

The wooden calendars were made by masters called calendaristi 'calendar makers', often coming from priest families. Vakarelski (1936) considers that Greek and Slavic monks in the Orthodox monasteries could have made such objects in order to distribute them further mainly to other local priests who would use them in their work among the peasants. Probably it is the activity of Greek priests among the Bulgarian Christians that we can associate with the wooden calendar from the region of Lozengrad (now in Turkey) (Koleva 2006: 100-101, Fig. 7). There are inscriptions with upper and lower case Greek let-

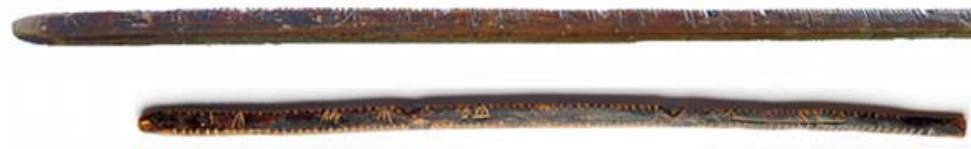

Figure 2. Wooden calendars from the Smolyan and Burgas regions (Koleva 2006: Fig. 3). 
ters on two of the sides around the date January 1. The year ' 1850 ' is also hewn out next to them.

The ethnographic studies enlist various names by which the wooden calendars were known: календар-рабош, тояга, прьчка, патерица [calendar-rabosh, toiaga, prachka, pateritsa]. The first name can be associated with the calendar's manufacture technique, while the rest - with its appearance and way of usage.

The word pàбош is considered to derive from the Slavic ryti 'burrow' or from the old Slavic * $r a b ъ$ (cf. $р ъ б$ 'edge') (Mladenov 1941; Anastasov \& Deikova et al. 2002). The name can be found in other Slavic languages as well: in SerboCroatian, Slovenian, Czech: ragoš, raboš, rovaš, rabuše; in Romanian and Albanian: răboş, rabój and rabūsh (from Bulgarian).

Very popular names are: тояга, прьчка 'stick, staff', патерица 'crutch' and even поп 'priest' (in the Hasekiya region in Strandzha) (Gorov 1997). Compare

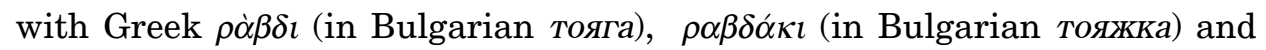
$\pi \alpha \tau \varepsilon \rho i \tau \sigma \alpha$ (in Bulgarian патерица).

Since they were hard, these objects sometimes had a very practical application as well: they were used as crutches or walking sticks, to support loads (on the back of the horses), or to stir the yarn while dyeing it. Shepherds and masons carried rabosh calendars with them when they had to travel far away.

Bulgarians used to call ра̀бош ог чѐтула (in Greek $\tau \sigma \varepsilon ́ \tau о v \lambda \alpha)$ the tallies that have a somewhat different function and appearance (Fig. 3). They were used by shepherds in dairies and by bakers to register the exchanged products.

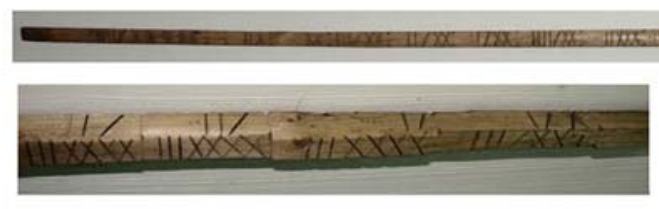

Figure 3. An accounting tally stick from Devin, Smolyan region. Photo by Nikolay Sivkov.

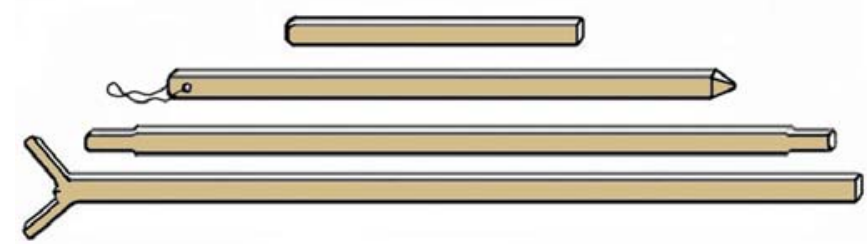

Figure 4. Different kinds of Bulgarian rabosh-calendars according to their shape and size. 
The rabosh-calendars (Fig. 2) are clearly distinguished by their shape and size, the type of the signs and the structure of the calendar record. They are made of well processed hardwood and are always four-sided sticks, $50-140 \mathrm{~cm}$ long and 1-3 cm wide, rarely with a well-shaped handle - either fork-shaped or straight. Sometimes there might be a hole in one of the ends to hang the stick by a thread).

Most of the Bulgarian wooden calendars represent the Julian (solar) calendar. The 365-366 day notches are carved on the edges. An interval, a groove or a narrower and longer notch separates the months from one another. On rare occasions, signs for a 7 or 10 days' division are in use.

Two main ways to distribute the day notches are used. The first one is to mark them on two adjacent or two opposite edges of the stick dividing the year into two groups of six months, and the second one (only in three cases) is to incise them on each of the four edges of the stick in groups of three (Figs. 2 and 5). Feast days are marked by various signs hewn into the sides of the sticks.

The fixed feasts follow the Eastern Orthodox liturgical year and the wooden calendars themselves represent a short record of the more important festivals of Virgin Mary, Jesus Christ, the Saints and Old Testament prophets. Bulgarian saints are also presented "заради заслуги към българската църква, религия и народа ни" 'due to their contribution to the Bulgarian Church, religion and our people', as Detev (1947) writes. Some of the marked days are related both to the astronomical and to the economic division of the year into seasons (Table 1).

There exists a group of three rabosh-calendars from the Kyustendil region which represent a specific kind of calendar writing (Koleva 1996). The foursided sticks are 1-3 cm wide and $74 \mathrm{~cm}, 100 \mathrm{~cm}$ and $130 \mathrm{~cm}$ long, respectively. What is remarkable about these is the uniformity of the signs and their combinations as well as the structure of the calendar record. The day notches totaling 354,365 and 378, respectively, are not grouped in months. There are marks dividing the weeks only on one of them and only on this stick the reading goes from one side to the other always in the same direction; that is, with interruption. It is possible to 'read' these calendars with the help of alternating 29- and 30-day-long periods. The presence of additional (extraordinary) day-marks on some places on the sticks and a group of signs 'XXX' on the end of each one, allows us to suggest that a 30-day-long month has been periodically added to reconcile the lunar and the solar year. The special signs in this case could mark the times of characteristic lunar phases. Most probably, a "wooden calendar" variant for Paschal calculations using the 19-year luni-solar cycle was also related to the religious cult. The signs used are predominantly a straight line, a bident and a trident. 
There is only one more calendar that is known from this region (Zakhariev 1929 ) and it belongs to the Julian (solar) type of calendars. The feast signs used are the same basic signs (see column 16 in Fig. 12). However, the months are separated in a different way, namely by a single ' $\mathrm{X}$ ' sign.

\section{THE STRUCTURE OF CALENDAR RECORDS. CALENDAR TYPOLOGY}

Typically, the Bulgarian calendars are read from one side to the other without interruption: for example, from right to left on one side and then from left to right on the other side, that is, boustrophedonically. In order to read the calendar record correctly the user needs to be familiar with the Julian calendar, the feast system used, and the combinations of feast and ordinary days. In the Orthodox tradition, the key to define the dates of the Sundays for the following year is March 2. For the calendars of the Western tradition with a beginning of the year on January 1, the dominical letter of the first Sunday will determine the Sunday letters for the whole year.

There are different beginnings of the calendar record on the sticks. In a group of 21 studied Bulgarian wooden calendars, three types were defined (Koleva 2006; 2007). The first type is with a starting day on September 1 and eight calendars from the regions of Smolyan (2), Haskovo (1), Kyustendil (1), and Burgas (4) belong here. There are inscriptions of the years '1783' and ' 1850 ' on two of them. Eleven calendars ( 10 from Smolyan and 1 from Burgas region) belong to the second type with beginnings in April or May and, respectively, in October or November. Here is a list of the registered starting dates: April 1-October 1 (on 1 calendar), April 20-October 26 (2), April 23-October 21 (1), April 23-October 23 (1), April 23-October 26 (1) and May 1-November 1 (5). There is an inscription '1818 (or 1878)' on one of them (Koleva 1967). In the folk economic calendar, these dates divide the year into a summer and a winter half. This is typical of the so-called 'shepherd's year' which was very popular in the Central Rhodopes until the 19th century (Dechov 1903). May be this is the reason why such a division has been predominant in the wooden calendars from this region as well. The third type is with a starting day on January 1 and there are two calendars with the inscription '1897' on one of them from the Smolyan region that belong here.

It is known from written sources that in Bulgaria different beginnings of the year (September 1, January 1, March 1) have been in use to a greater or lesser extent ever since the 14th to 15th century. The ecclesiastical year begins on September 1 and in the Menaion ('Book of Months') and other service 
books it is noted as Nово лето 'New year' and/or ов индикт 'New Indiction'. The beginning of the indictional year of the Byzantine Empire could also fall on September 23.

\section{WOODEN CALENDARS FROM THE VILLAGE OF POLKOVNIK SERAFIMOVO, SMOLYAN REGION}

Four objects from the village of Polkovnik Serafimovo, Smolyan region are presented on Figure 5 as an illustration of the above. These are kept in museums in Sofia (S1 and S2) and Smolyan (S4), and in private possession (S3) (Koleva 2008). All of these are four-sided, with different size and beginning of the calendar year. We can observe two typical ways of separating the months from one another - with an interval and with a groove. The reading of the calendar writing follows without interruption.

The first two calendars (S1 and S2) are about $50 \mathrm{~cm}$ long and exhibit a striking resemblance. It is obvious that they were made by the same hand. The day notches are divided into four groups of three months on the four edges. Only here the beginning date of the calendar records is January 1. On the first of the sticks a number, probably the year $1897 \mathrm{CE}$ is incised. Here tiny scratches and round grooves made with some sharp tool mark sporadic dates and can be defined as "auxiliary" and used to determine the Sundays and the moveable feasts, for instance. Cyrillic letters ' $\mathrm{H}$ ' are writen next to some of them. It is possible that these stand for the Bulgarian word неделя 'Sunday'.

The owner of the third calendar (S3) was a chief shepherd (kehaya) named Hubcho Kehaya. The length of the stick is about $80 \mathrm{~cm}$. The day notches of the year are divided into two groups of six months, incised on two opposite edges of the stick. The beginning of the calendar record is May 1 on the one side and November 1 on the other side. There are Christian symbols, anthropomorphic and zoomorphic figures on the four sides of the handle.

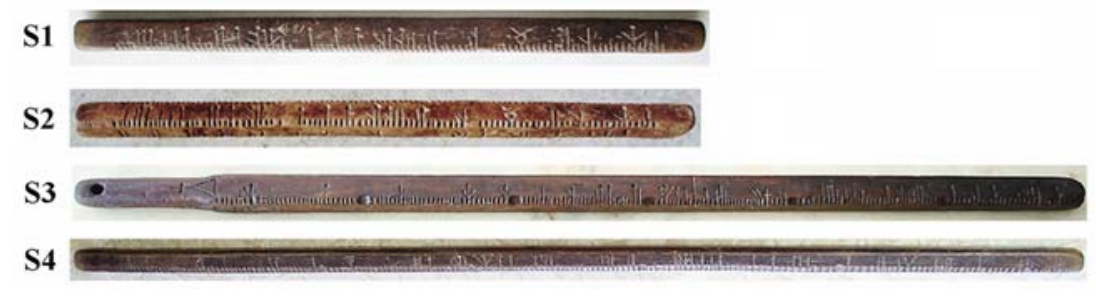

Figure 5. Four wooden calendars from the village of Polkovnik Serafimovo, Smolyan region (Koleva 2008: Fig. 2). 
The fourth calendar from Polkovnik Serafimovo (S4) belongs to a family from the clan of the above-mentioned Hubcho Kehaya. The beginning of the calendar record is April 23 on the one side and October 21 on the other side. The calendar also has one special feature: a very big groove is incised between the months of February and March. Maybe the date March 1 was important for some calendar calculations. The leap day is marked with a long thin line.

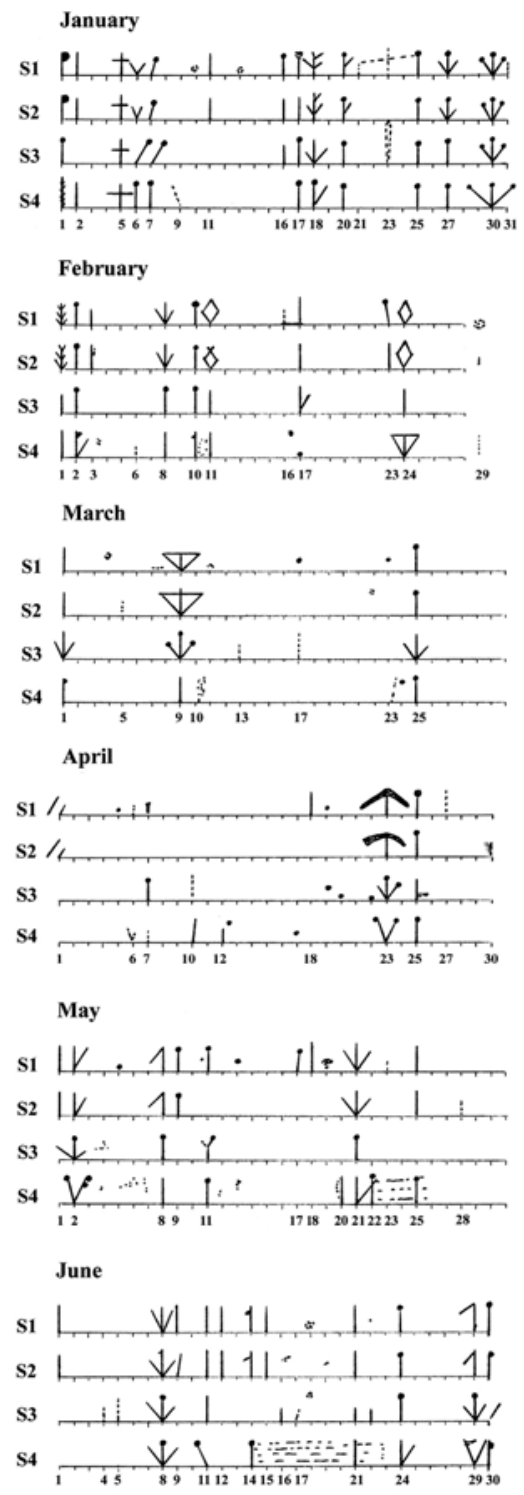

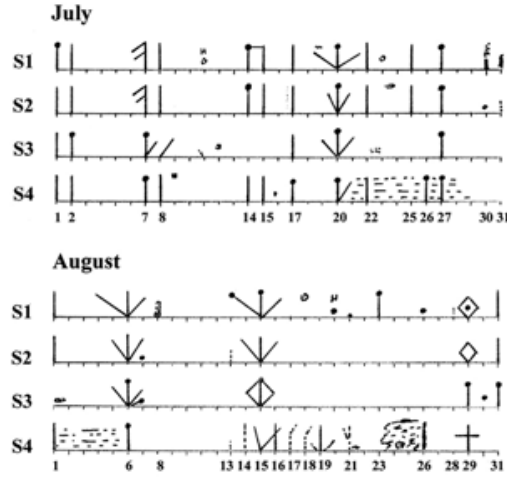
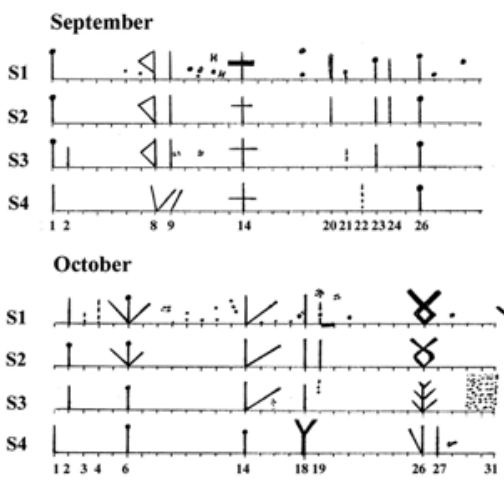

November

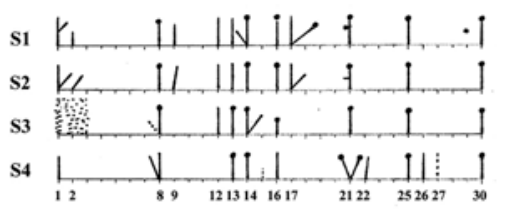

December

si $+x i k, i T, 1,1,11$,

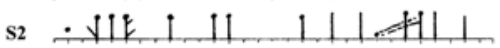

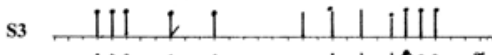

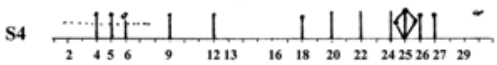

Figure 6. Comparative scheme of the distribution of the feast signs on the four calendars from Polkovnik Serafimovo (Koleva 2008: Fig. 10). 
The basic signs used are a straight line, a bident, and a trident, often with a small groove on their tips. Some of the significant festivals are marked with different geometrical symbols. The distribution of the day notches and the feast signs is shown schematically in Figure 6.

In Table 1 (see the Appendix) the more clearly marked dates on the four calendars from Polkovnik Serafimovo in the Central Rhodopes are identified with the fixed feast days of the Orthodox calendar. The popular festival and months' names (including those in the local dialect) of some of them are given in italics.

It turns out that about 75 dates out of the total 135 identified as Christian festivals are among the most popular feasts in the Bulgarian folk calendar with their own or Christian names. On most of them, besides the public celebration, some magic activities with water and fire are carried out meant to protect the health and the life of the people. Other folk rites are of prophesying as well as of cognitive nature and serve the needs of agriculture and livestock breeding.

\section{WOODEN CALENDARS FROM OTHER COUNTRIES}

\section{Croatia}

A very close parallel to our two January-type calendars from Polkovnik Serafimovo is a Croatian wooden calendar (ragoš) from the Dalmatian island of Olib. It is a four-sided stick ( $3 \mathrm{~cm}$ wide and about $66 \mathrm{~cm} \mathrm{long}$ ) with a four-fold structure of the calendar record and a beginning on January 1 (Gavazzi 1938). The first difference, however, is in the direction of reading. Here we read the calendar record one-way only (from left to right in Fig. 7), which means that the
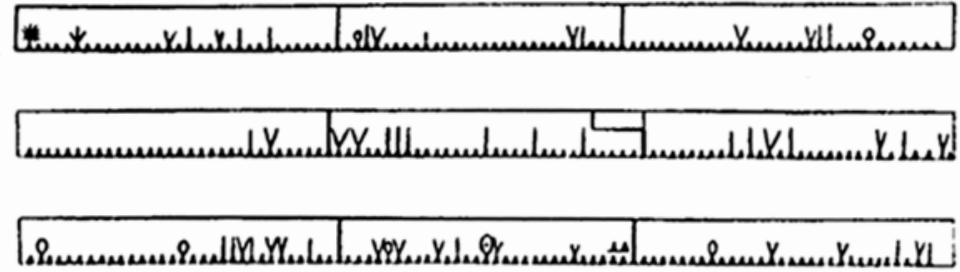

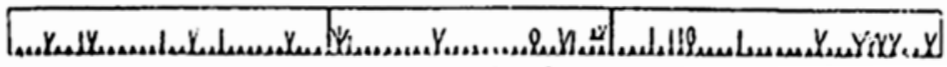

Figure 7. Scheme of a wooden calendar ragoš from the Dalmatian island Olib (Gavazzi 1938: 3, Fig. 2) 
reading is interrupted. The second difference is in the feast system used, because the Croatian calendar reflects the liturgical calendar of the Western Church and some local tradition.

\section{Komi (Russia)}

The wooden calendar from the village of Vizinga, Sysolsk region in Komi (Russia) (Fig. 8) was first described by Günter Stipa (1966: 190). This and another five wooden calendars (pas, pu svyatsi) used by Komi hunters are kept in the National Museum of Syktyvkar and have been published by Vladimir Lipin (2006).

According to Stipa, the calendar of Vizinga is of a more archaic type and can be compared to the wooden calendars from the Balkans. It is a four-sided, 104 cm long calendar stick. The day notches are hewn on two adjacent sides, and on the other two sides the respective feast dates are marked. There are C-shaped signs incised between the months, whose open part points to the direction of reading. The beginning of the calendar record is January 1 and right before this date there is a CC-sign (double ' $\mathrm{C}$ '). The $\mathrm{C}$ sign before March 1 is highlighted by an additional short tilted line. The reading of the record is boustrophedonic, without interruption. The basic signs used are long straight lines and only in one case the line is short. In three cases a bident and only once a trident is used to mark feasts. The feast dates correspond to the Eastern Orthodox liturgical calendar with the characteristic local Komi festivals (Lipin 2006).

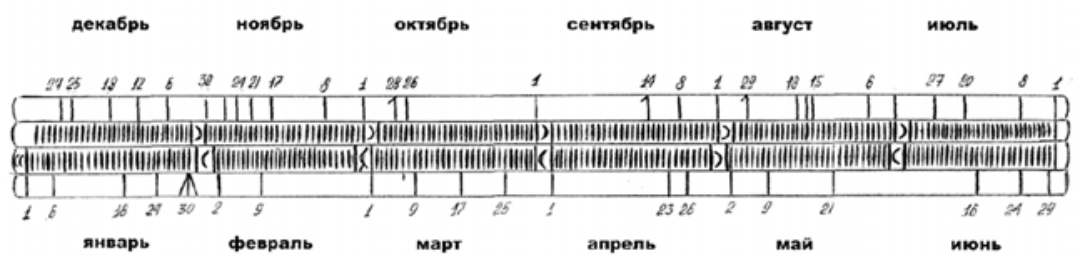

Figure 8. Scheme of the wooden calendar from the village of Vizinga, Sysolsk region in Komi, Russia (Lipin 2006: 124, Fig. 2).

Figure 9. Zyryan pas-calendar (Savvaitov 1869: 409). 
The wooden calendar from Vizinga differs substantially in its appearance from the 6-sided bipyramidal (20-25 cm long) pas-calendars or pu suyatsi (Fig. 9), used by the Komi hunters (Stipa 1966; Savvaitov 1869; Sreznevskii 1876; Lipin 2006).

\section{Finland}

Finland is in the contact zone of the Western and the Eastern Church. Among the numerous runic calendars there are some Orthodox calendar sticks belonging to the Finnish and Finno-Ugric collections of the National Museum of Finland (Koleva \& Koleva 2006). For all of these the commonly used names are riimusauva ('runic stick') and kalenterisauva ('calendar stick'), or puukalenteri ('wooden calendar') and riimukalenteri ('runic calendar').

The two types of wooden calendars can be easily distinguished at first glance (see Figs. 10 and 11). The Orthodox wooden calendars are simpler in appearance and have a different method of time reckoning compared to the runic calendars.

The length of the sticks varies from $40 \mathrm{~cm}$ to $70 \mathrm{~cm}$. These are three-, fouror six-sided, often with a handle and an opening for hanging. The day notches are incised on all of their edges. Two typical ways of separating the months can be distinguished - with an interval or with a groove. Often the Russian month names or their first letters are engraved in Cyrillic letters. The calendar record starts usually with the date March 1 and only very rarely - with September 1 . The reading of the record begins from one and the same end (usually from the handle if there is one) to the other end. The day notches are 365 or 366, including the leap day. Mainly Christian symbols - cross, parts of the cross, swastika, circles and their combinations - are used to mark the feast dates (see the signs

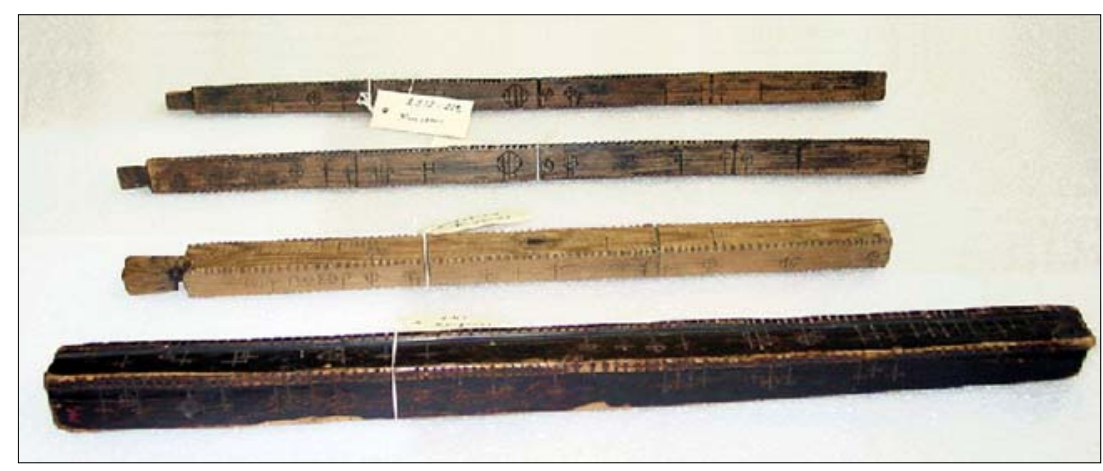

Figure 10. Orthodox wooden calendars from the National Museum of Finland (Koleva \& Koleva 2006: 156, Fig. 6) 


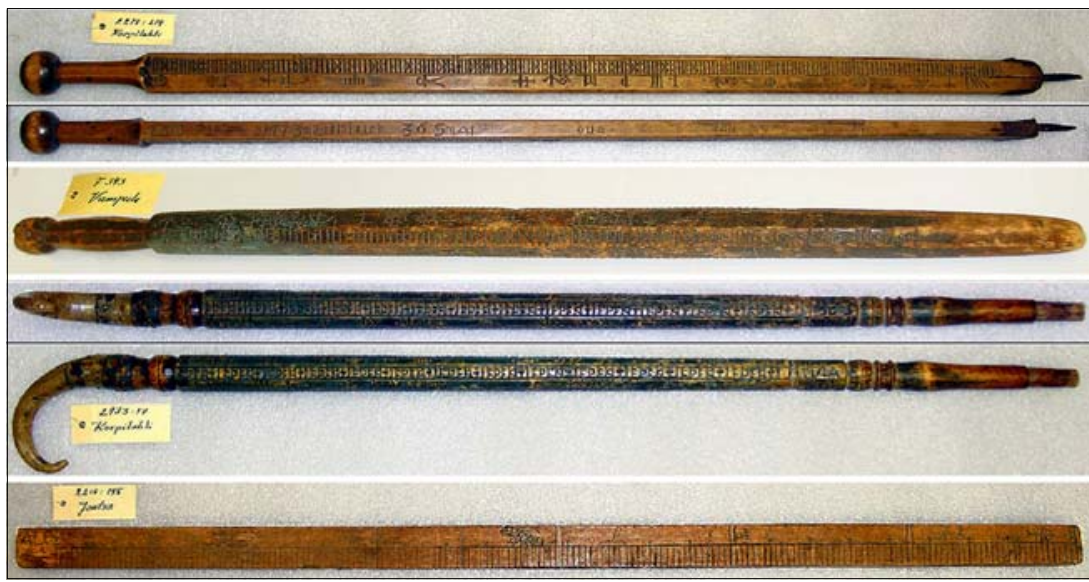

Figure 11. Runic calendars from the National Museum of Finland (Koleva \& Koleva 2006: 154-155, Fig. 4 and Fig. 5)

in the last two columns in Fig. 12). The dates of important astronomical events and climatic conditions are marked as well.

The fixed feast days reflect the Orthodox liturgical calendar with its local peculiarities. The wooden sticks originate from Eastern Finland and Northwestern Karelia in Russia. According to one tradition, an Athonite monk, Sergius, sent by the Byzantine Emperor had reached as far as Lake Ladoga and with his Karelian companion, Herman, they founded the Valaam Orthodox Monastery in 10th century. Most probably, it was him who carried there the Byzantine Church calendar (Stipa 1966: 205; 'Sergius of Valaam'). The Russian Church has also left its traces on the feast calendar and the official language of the mass until the 19 th century.

The runic calendars in the Finnish collection show the characteristic peculiarities of the runic calendars in the Nordic lands as well as some local features (Fig. 11). These vary in size and shape, type of the symbols and pictograms, as well as in the structure of the calendar records. Some Estonian runic calendars are kept in the Estonian collection of the National Museum of Finland, as well as in the Estonian National Museum in Tartu, Estonia.

\section{SIGNS ON THE WOODEN CALENDARS}

The basic signs used are a straight line, bident and trident (Fig. 12). Their more complex and ornamented variants mark the more significant feasts. Very rarely Cyrillic letters are used. For example, on the rabosh from Lyulyakovo 

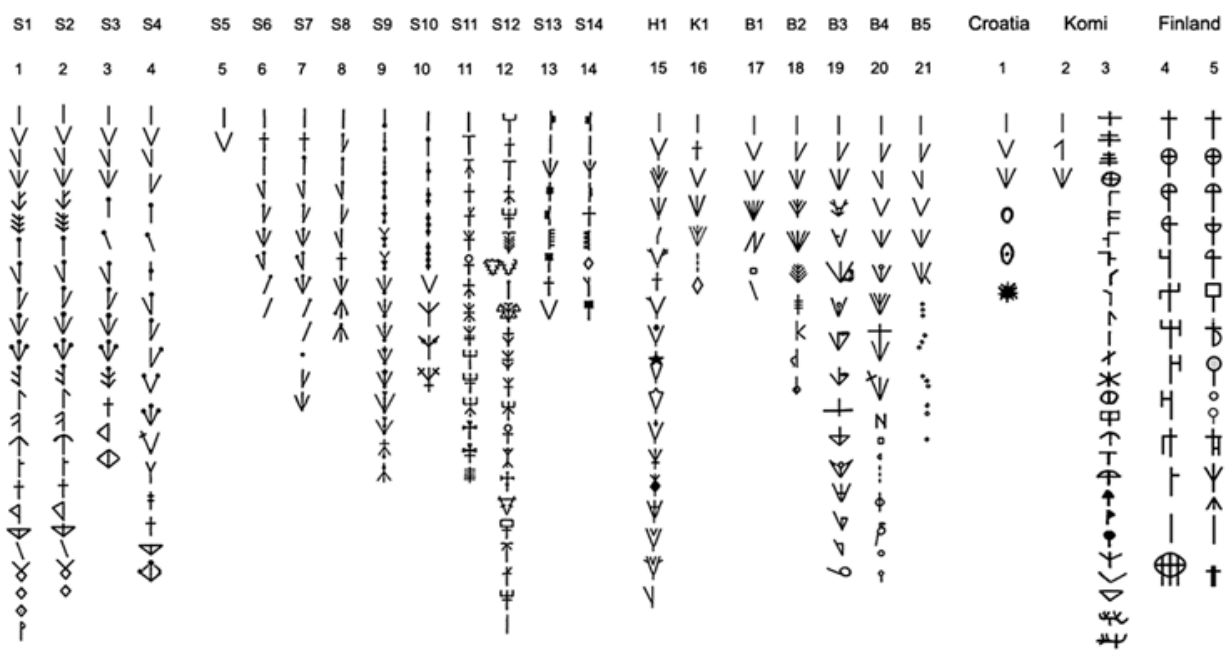

Figure 12. Signs on 21 Bulgarian calendars from the Smolyan (S), Haskovo (H), Kyustendil $(K)$ and Burgas $(B)$ regions in comparison with 1 from Croatia, 2 from Komi (Russia) and 2 from Finland. The signs in the first four columns are from Polkounik Serafimovo (Koleva 2008: Fig. 9)

(B3) some important days are marked with a ' $\mathrm{C}$ ' for Сурва [Surva] (the folk name of January 1), 'Д' for Димитровден [Dimitrovden] (October 26), 'A' for Архангеловден [Arhangelovden] (November 8), and so on. A cross on one of the ends of the stick points to the beginning of the calendar record September 1, which is the beginning of the Church year (Koleva \& Georgiev 2006; Koleva 2007).

In the middle of the 9th century, Bulgaria was converted to Christianity with Byzantium's assistance. The type of signs on the calendar sticks speaks of a pre-Christian and early Christian writing tradition. Some of them have counterparts among the Proto-Bulgarian ideographic signs found on archaeological artifacts from the 7th-10th century in the old Bulgarian capitals and sanctuaries in Pliska, Madara and Preslav (Donchev 1971; Doncheva-Petkova 1980; Sefterski 2001). Similar signs are also found among the damga signs and brands used by shepherds in the Rhodope Mountains to mark the animals belonging to a particular owner (Manolova 1980). This confirms their universality and strong local tradition on the Balkans.

The first four columns in Figure 12 present a homogeneous group of signs on the calendars from Polkovnik Serafimovo (Figs. 5 and 6). Both the typical features of the Bulgarian calendar signs, and the local ones stand out and can be easily distinguished. By comparison, signs from the Smolyan (S), Haskovo $(\mathrm{H})$, Kyustendil (K) and Burgas (B) regions as well as from Croatia (Gavazzi 1938), Komi (Russia) (Lipin 2006; Savvaitov 1869) and Finland (Koleva \& Koleva 2006) are included. 
As a whole the Balkan calendar sign tradition of Bulgaria and Croatia stands out in comparison to the more northern cultures of Finland and Komi (the calendar of Vizinga ("Komi 2") is an exception).

\section{CONCLUSIONS}

The wooden calendars reviewed in the present work belong to the type of eternal calendars, used by the Christians to track the liturgical year of the Christian Church. It has been supposed that the wooden calendars were spread initially by missionaries and later also by zealous Christians, especially in times of trial and ordeal for the Christian faith.

It is possible that the two types of wooden calendars from Bulgaria make up a set of time-reckoning devices for the needs of the Christian clerks in the monasteries and churches. The first type bears the structure of the Julian solar calendar. The more important fixed feasts of the Eastern Orthodox calendar of saints are marked with special signs. Most of the known Bulgarian wooden calendars belong to this type. The second type is represented only by three objects from the region of the town of Kyustendil. Here special signs have been used to track the weekdays (in one case) and the lunar phases. Such calendars could be used to determine the moveable feasts in the Paschal cycle.

The comparison of the marked feast dates on the wooden calendars, with the traditional folk festivals in Bulgaria, demonstrates the syncretism, the coexistence and mutual penetration of the pagan tradition and the Orthodox religious ritualism. The distinct calendar typology evidences the different priorities of the timekeeping. While for the clergy it was important to consolidate the Christian community through the law of the Orthodox liturgical year, for the ordinary people it was necessary to predict the seasonal changes and to plan their economic activities, based on long observations and experience.

The parallels with calendars from the neighbouring and more distant countries of the world demonstrate the existence of certain canonic rules in the making of the calendar devices. The comparative analysis shows their common as well as unique features, the latter being due to the differences in local traditions. 


\section{APPENDIX}

Table 1. Identification of the marked dates on four calendars from the village of Polkovnik Serafimovo, Smolyan region with the fixed Orthodox feasts, their folk names and customs, and the number of occurrences.

\begin{tabular}{|c|c|c|}
\hline Date & September (Septemvri, Rùyen) & \# \\
\hline 1 & $\begin{array}{c}\text { Beginning of the Ecclesiastical New Year; } \\
\text { Venerable Simeon Stylites (Simeonovden- } \\
\text { the day of the first Autumn sow) }\end{array}$ & 4 \\
\hline 2 & $\begin{array}{l}\text { St Mamas of Caesarea, Martyr; } \\
\text { St John the Faster of Constantinople }\end{array}$ & 1 \\
\hline $3-8$ & $\begin{array}{c}\text { Bruenite dene - the days from September } 3 \\
\text { to } 8 \text {. They show what the weather will be like } \\
\text { in the next six months of the autumn and the } \\
\text { winter, i.c. from October till March. }\end{array}$ & \\
\hline 8 & $\begin{array}{c}\text { Nativity of the Virgin Mary (Malka } \\
\text { Bogoroditsa, Malka Cherkva) }\end{array}$ & 4 \\
\hline 9 & $\begin{array}{c}\text { Afterfeast of the Nativity of the Virgin Mary; } \\
\text { SS Joachim and Anne }\end{array}$ & 4 \\
\hline 14 & $\begin{array}{c}\text { Exaltation of the Holy Cross (Krastovden, } \\
\text { Karstovden) }\end{array}$ & 4 \\
\hline 20 & St Eustathius, Megalomartyr & 2 \\
\hline 21 & Apodosis of the Exaltation of the Holy Cross; & 2 \\
\hline 23 & Conception of St John the Baptist & 3 \\
\hline 24 & St Thecla, Protomartyr & 2 \\
\hline 26 & $\begin{array}{c}\text { Dormition of St John the Theologian, Apostle } \\
\text { and Evangelist }\end{array}$ & 4 \\
\hline \multicolumn{3}{|c|}{ October (Dimitrovski mesets, Dimitroske) } \\
\hline 1 & Feast of the Protective Veil of the Virgin Mary & 1 \\
\hline 2 & $\begin{array}{l}\text { St Justina of Nicomedia, Martyr St Justina } \\
\text { (Ustina - from 'Justina') }\end{array}$ & 3 \\
\hline 6 & St Thomas, Apostle & 4 \\
\hline 14 & $\begin{array}{l}\text { Venerable Petka (Parasceve) of Turnovo } \\
\text { (Petkovden). A feast of the stock-breeders. }\end{array}$ & 4 \\
\hline 18 & St Luke, Apostle and Evangelist & 4 \\
\hline 19 & $\begin{array}{l}\text { Transfer of the Relies of Venerable Joln of } \\
\text { Rila in Bulgaria; Prophet Joel }\end{array}$ & 3 \\
\hline 26 & $\begin{array}{l}\text { St Demetrius of Thessalonica, Megalomartyr } \\
\text { [Dimitrovden, Mitrovden, Razpust (break- } \\
\text { up)]. The economic year is over, the hired } \\
\text { hand is dismissed. People predict the weather } \\
\text { in the next months. Beginning of the winter } \\
\text { half-year. }\end{array}$ & 4 \\
\hline 27 & $\begin{array}{c}\text { St Nestor of Thessalonica, Martyr [Sv. Nistor, } \\
\text { Mishinden (Mouse Day), Razpustene]. Magic } \\
\text { acts are performed to keep away the mice. }\end{array}$ & 1 \\
\hline \multicolumn{3}{|c|}{ November (Rangelov mesets, Gergyòske) } \\
\hline 1 & $\begin{array}{l}\text { SS Cosmas and Damian the Silverless of } \\
\text { Mesopotamia, Miracle Workers }\end{array}$ & 3 \\
\hline 2 & $\begin{array}{c}\text { SS Acindynus, Pegasius, Aphthonius, } \\
\text { Elpidephorus and Anempodistus of Persia, } \\
\text { Martyrs }\end{array}$ & 2 \\
\hline
\end{tabular}

\begin{tabular}{|c|c|c|}
\hline 8 & $\begin{array}{c}\text { Synaxis of St Archange] Michael } \\
\text { [Arahàngelovden, Ràngelovden, Sv. Ràngel } \\
\text { dushovàdnik (The saint who takes the souls)] }\end{array}$ & 4 \\
\hline 9 & $\begin{array}{c}\text { SS Onesiphorus and Porphyrius of Ephesus, } \\
\text { Martyrs }\end{array}$ & 2 \\
\hline 12 & St John the Merciful of Alexandria & 3 \\
\hline 13 & St John Chrysostom of Constantinople & 4 \\
\hline 14-21 & $\begin{array}{l}\text { Mràtintsi, Wolf Days - the days up to } \\
\text { November } 21 \text { are very dangerous for health. } \\
\text { They are worse than the Mrasnite ('impure') } \\
\text { days from December } 25 \text { to January } 6 \text {. }\end{array}$ & \\
\hline 14 & $\begin{array}{c}\text { Beginning of the Nativity Fast; } \\
\text { St Philip, Apostle (Philip, Mratinyak, } \\
\text { Mràtintsi) }\end{array}$ & 4 \\
\hline 16 & St Matthew, Apostle and Evangelist & 4 \\
\hline 17 & St Gregory of Neocaesarea, Miracle Worker & 2 \\
\hline 21 & $\begin{array}{l}\text { Presentation of the Virgin Mary in the Temple } \\
\text { [Valcha Bogoroditsa (Wolf Virgin Mary), } \\
\text { Kutsulan (the Lame "Wolf')]. } \\
\text { Weather forecasts related to the bees. }\end{array}$ & 4 \\
\hline 22 & SS Philemon, Archipus and Appia, Apostles & 1 \\
\hline 25 & $\begin{array}{l}\text { Apodosis of the Presentation of the Virgin } \\
\text { Mary; } \\
\text { St Catherine of Alexandria, Megalomartyr } \\
\text { (Sw Katerina) } \\
\text { The saint protects against measles. Magic acts } \\
\text { arc performed to kecp away the mice. }\end{array}$ & 4 \\
\hline 26 & $\begin{array}{c}\text { Venerable Alypius Stylites [Zimen Sveti } \\
\text { Geòrgi (Winter St George)] }\end{array}$ & 1 \\
\hline 27 & Venerable Theodosius of Tarnovo (Bulgarian) & 1 \\
\hline 30 & $\begin{array}{l}\text { St Andrew the First-called, Apostle [Sv. } \\
\text { Andrey, Andreevden, Edrey ('to become } \\
\text { bigger, to grow up', e.g., related to the day- } \\
\text { folk etymology), Mechkinden (Bear Day)] }\end{array}$ & 4 \\
\hline \multicolumn{3}{|c|}{ December (Nikulski mesets, Nikùltske) } \\
\hline 2 & Prophet Habacuc & 2 \\
\hline 4 & $\begin{array}{c}\text { St Barbara of Hieliapolis, Megalomartyr ( } \boldsymbol{S} \boldsymbol{v} \\
\text { Varvara) }\end{array}$ & 4 \\
\hline 5 & Venerable Sabbas the Sanctified ( $S_{v} \cdot$ Sava $)$ & 4 \\
\hline 6 & $\begin{array}{c}\text { St Nicholas of Myra in Lycia, Miracle Worker } \\
\text { [Sv. Nikola, Nikulden, Riben Sv. Nikola } \\
\text { (from riba 'fish')] }\end{array}$ & 4 \\
\hline 9 & Conception of the Virgin Mary by St Anne & 4 \\
\hline
\end{tabular}




\begin{tabular}{|c|c|c|}
\hline 12 & $\begin{array}{l}\text { Venerable Spiridon of Trimythus, Miracle } \\
\text { Worker (Sv. Spiridon) } \\
\text { The saint protects against measles. }\end{array}$ & 4 \\
\hline 13 & St Lucy of Syracuse, Martyr & 2 \\
\hline 18 & $\begin{array}{c}\text { St Sebastian of Rome, Martyr; St Modestus of } \\
\text { Jerusalem }\end{array}$ & 4 \\
\hline 20 & $\begin{array}{l}\text { Forefeast of the Nativity of Jesus; } \\
\text { St Ignatius the Theophoros of Antioch } \\
\text { [Ignazhden, Ignat, Edinak 'Loner' (folk } \\
\text { etymology), Polyazov den 'First Guest } \\
\text { Mceting'] } \\
\text { The first guest on that day may bring luck or } \\
\text { misfortune to the house. }\end{array}$ & 4 \\
\hline 22 & $\begin{array}{c}\text { St Anastasia, Megalomartyr [Sv. Nashtashe } \\
\text { (from Anastasia - folk pronunciation in the } \\
\text { Central Rhodopes), Sv. Chorna (from cheren } \\
\text { 'black')] } \\
\text { The saint should be worshipped in order not to } \\
\text { ruin people. }\end{array}$ & 4 \\
\hline 24 & $\begin{array}{c}\text { Nativity Eve; } \\
\text { Venerable Eugenia of Rome, Martyr } \\
\text { (Malka Koleda, Suha Koleda, } \\
\text { Krachun }) \\
\text { Magic rites and auguries. }\end{array}$ & 2 \\
\hline 25 & $\begin{array}{l}\text { Nativity of Jesus (Koleda, Golyama Koleda, } \\
\text { Bozhich). The biggest winter feast. Magic } \\
\text { ritcs and augurics. The sun is in its lowest } \\
\text { point and possesses least power. It takes a turn } \\
\text { towards the summer. }\end{array}$ & 4 \\
\hline $\begin{array}{l}25.12 \text {. } \\
-6.01\end{array}$ & $\begin{array}{c}\text { Mrasnite 'impure', Poganite 'pagan', } \\
\text { Nekrastenite 'unbaptized' dene - the days } \\
\text { from December } 25 \text { to January } 6 \text { are very } \\
\text { dangerous. }\end{array}$ & \\
\hline 26 & Synaxis of Virgin Mary & 4 \\
\hline 27 & $\begin{array}{l}\text { Afterfeast of the Nativity of Jesus; } \\
\text { St Stephen, Apostle, Archdeacon and } \\
\text { Protomartyr (Stefunovden) }\end{array}$ & 4 \\
\hline 29 & $\begin{array}{l}\begin{array}{l}14,000 \text { Holy Infants killed by Herod in } \\
\text { Bethlehem [Izklanite detsa (the killed } \\
\text { children)]. }\end{array} \\
\text { The day is honored by the women who have } \\
\text { up to three-year-old children. }\end{array}$ & 2 \\
\hline & January (Golyam Sechko, Golemin) & \\
\hline 1 & $\begin{array}{l}\text { Circumcision of Jesus; St Basil the Great } \\
\text { (Surva, Vasilyovden, Obrezanie) } \\
\text { Rites are performed to keep away the bears } \\
\text { and the wolves. }\end{array}$ & 4 \\
\hline 2 & $\begin{array}{l}\text { St Silvester of Rome (Sv. Silvestri, } \\
\text { Karamanovden, Rinachovden) } \\
\text { Ox Day. The cowsheds are cleaned up. }\end{array}$ & 3 \\
\hline
\end{tabular}

\begin{tabular}{|c|c|c|}
\hline 5 & $\begin{array}{l}\text { Eve of the Epiphany; } \\
\text { Feast of the Holy Cross [Korst (from Krast } \\
\text { 'Cross')] }\end{array}$ & 4 \\
\hline 6 & $\begin{array}{c}\text { Epiphany (Bogoyavlenie, Vordantovden, } \\
\text { Voditsi) }\end{array}$ & 4 \\
\hline 7 & Synaxis of St John the Baptist (Ivanovden) & 4 \\
\hline 11 & Venerable Theodosius the Great & 2 \\
\hline 16 & $\begin{array}{c}\text { Feast of the Chains of St Peter [Sveti Verigi } \\
\text { (from verigi 'chains')], Petrovo vazhe (Peter's } \\
\text { 'rope') }\end{array}$ & 3 \\
\hline 17 & Venerable Anthony the Great (Antonovden) & 4 \\
\hline 18 & $\begin{array}{c}\text { St Athanasius the Great [Ataniasovden, Zimen } \\
\text { Sv. Atanas (Winter St Atanas), Srede zima } \\
\text { (Midwinter)] }\end{array}$ & 4 \\
\hline 20 & $\begin{array}{l}\text { Venerable Euthymius the Great; St Euthymius } \\
\text { of Tarnovo } \\
\quad \text { Petlyovden (Cock Day), Black Day }] \\
\text { Black cock was slaughtered for the wellbeing } \\
\text { of small boys. }\end{array}$ & 4 \\
\hline 25 & $\begin{array}{l}\text { St Gregory the Theologian of } \\
\text { Constantinople }\end{array}$ & 4 \\
\hline 27 & $\begin{array}{l}\text { Transfer of the Relics of St John } \\
\text { Chrysostom }\end{array}$ & 4 \\
\hline 30 & $\begin{array}{l}\text { Synaxis of the Three Hierarchs [Tri } \\
\text { svetiteli (Three Saints)] }\end{array}$ & 4 \\
\hline \multicolumn{3}{|c|}{ February (Malak sechko, Malkin) } \\
\hline 1 & $\begin{array}{c}\text { Forefeast of the Presentation of Jesus in the } \\
\text { Temple; } \\
\text { St Tryphon of Campsada, Martyr (Sv. Trifon, } \\
\text { Trifonovden, Zarezan) } \\
\text { First Spring Feast. People worship } \\
\text { St Tryphon, the master of the wolves and a } \\
\text { patron of the vine-growers. The vines are cut } \\
\text { symbolically and get watered with wine. The } \\
\text { feast originates from the Dionysian festival in } \\
\text { Ancient Greece. }\end{array}$ & 4 \\
\hline 2 & $\begin{array}{c}\text { Presentation of Jesus in the Temple [Ovcha } \\
\text { Bogoroditsa (Sheep Virgin Mary)] } \\
\text { Weather forccasts related to the becs. }\end{array}$ & 4 \\
\hline 3 & St Simeon and Anne the Prophetess & 2 \\
\hline 8 & $\begin{array}{l}\text { St Theodore the General, Megalomartyr; } \\
\text { Prophet Zachariah [Zimen Todorovden } \\
\text { (Winter St Todor)] }\end{array}$ & 4 \\
\hline 10 & $\begin{array}{l}\text { St Charalampus of Magnesia, Martyr }[S v \\
\text { Haralambi, Chumin den (Plague Day) }]\end{array}$ & 4 \\
\hline 11 & $\begin{array}{l}\text { St Blaise of Sebastia, Martyr [Sv. Vlas, } \\
\text { Vlasovden, Mukovden (from mucha 'moo')] } \\
\text { St Vlas protects the oxen against the lethal } \\
\text { disease vlas. }\end{array}$ & 4 \\
\hline 17 & $\begin{array}{c}\text { St Theodore Tiro, Megalomartyr (Sv. Todor) } \\
\text { The saint protects the horses. }\end{array}$ & 3 \\
\hline
\end{tabular}




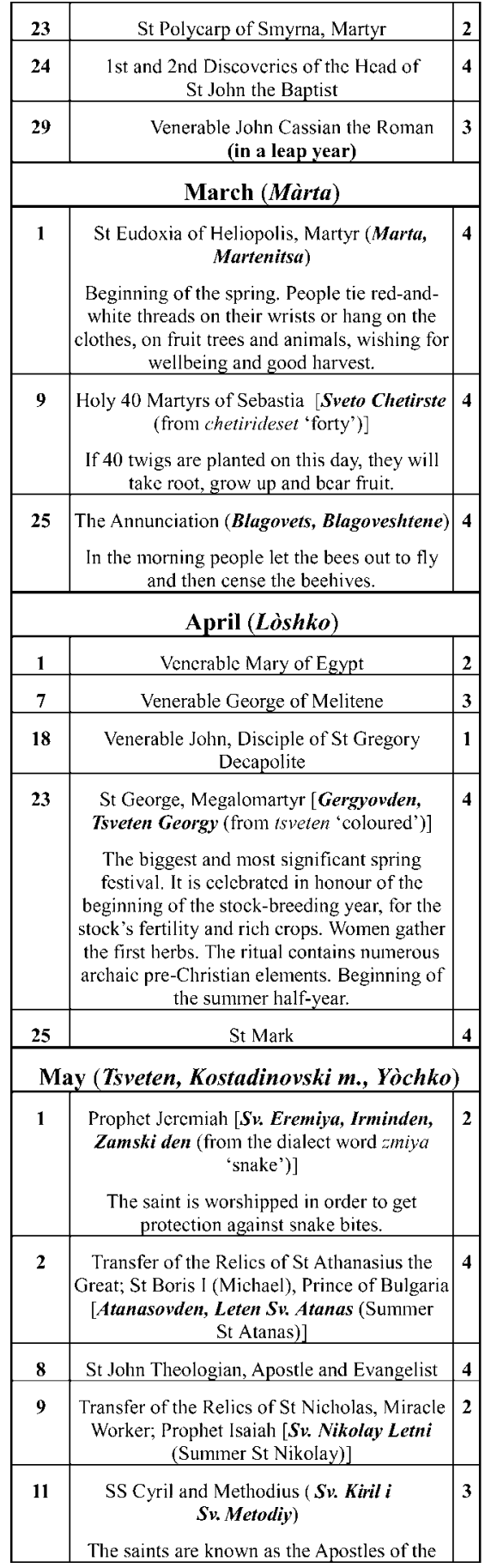

\begin{tabular}{|c|c|c|}
\hline & $\begin{array}{l}\text { Slavs. They are credited with devising the } \\
\text { Glagolitic alphabet in } 855 \text {, the first alphabet } \\
\text { used to transcribe the Old Church Slavonic } \\
\text { language. The church feast day is celebrated } \\
\text { in Bulgaria since } 1855 \text { and in Europe since } \\
1979 .\end{array}$ & \\
\hline 17 & SS Andronicus and Junia, Apostles & 1 \\
\hline 18 & $\begin{array}{l}\text { SS Peter, Dionysius, Andrew, } \\
\text { Paul, Christina, Martyrs }\end{array}$ & 1 \\
\hline 20 & St Thallelaeus the Merciful, Martyr & 1 \\
\hline 21 & $\begin{array}{l}\text { SS Constantine, Emperor, and his } \\
\text { Mother Helen [Kostadin, Sveti Kostadin i } \\
\text { Elena, Predoy (from doya 'milk')] } \\
\text { In the Central Rhodopes this is a shepherd } \\
\text { feast. The shepherds wean the lambs and } \\
\text { collect the first milk. In Strandzha the so- } \\
\text { called nestinari dance is performed on } \\
\text { glowing embers, holding the saints' icon in } \\
\text { hand, and the future is predicted. }\end{array}$ & 4 \\
\hline 22 & St Basiliscus of Comana, Martyr & 1 \\
\hline 25 & $\begin{array}{l}\text { 3rd Discovery of the Head of John the } \\
\text { Baptist }\end{array}$ & 3 \\
\hline \multicolumn{3}{|c|}{ June (Enyovski mesets, Tòduroske) } \\
\hline 1 & St Justin the Philosopher, Martyr & 2 \\
\hline 8 & $\begin{array}{l}\text { Transfer of the Relics of St Theodore the } \\
\text { General, Megalomartyr [Leten Todorovden } \\
\text { (Summer St Todor)] }\end{array}$ & 4 \\
\hline 9 & St Cyril of Alexandria & 2 \\
\hline 11 & $\begin{array}{l}\text { SS Bartholomew and Barnabas, Apostles ( } \boldsymbol{S v} \text {. } \\
\text { Vartlomey, Sv. Fartulumey) } \\
\text { The saint is worshipped so that he would not } \\
\text { punish the people with hails and storms. } \\
\text { It is believed that on this day the Sun takes a } \\
\text { turn to the winter. }\end{array}$ & 4 \\
\hline 12 & $\begin{array}{l}\text { Venerables Onuphrius the Great and Peter the } \\
\text { Athonite }\end{array}$ & 2 \\
\hline 14 & $\begin{array}{c}\text { Prophet Elisha (Lisey) } \\
\text { The saint is worshipped so that she would not } \\
\text { punish the people with hails and storms. }\end{array}$ & 3 \\
\hline 15 & $\begin{array}{l}\text { Prophet Amos (Vidovden) } \\
\text { Vida, the sister of the Saints Vartlomey and } \\
\text { Elisha, is worshipped. Working is not } \\
\text { permitted. }\end{array}$ & 2 \\
\hline 16 & St Tychon of Amathus, Miracle Workers & 1 \\
\hline 21 & $\begin{array}{l}\text { St Julian of Tarsus, Martyr [Ulyan (from } \\
\text { 'Julian')] }\end{array}$ & 4 \\
\hline 22 & St Eusebius of Samosata & 1 \\
\hline
\end{tabular}




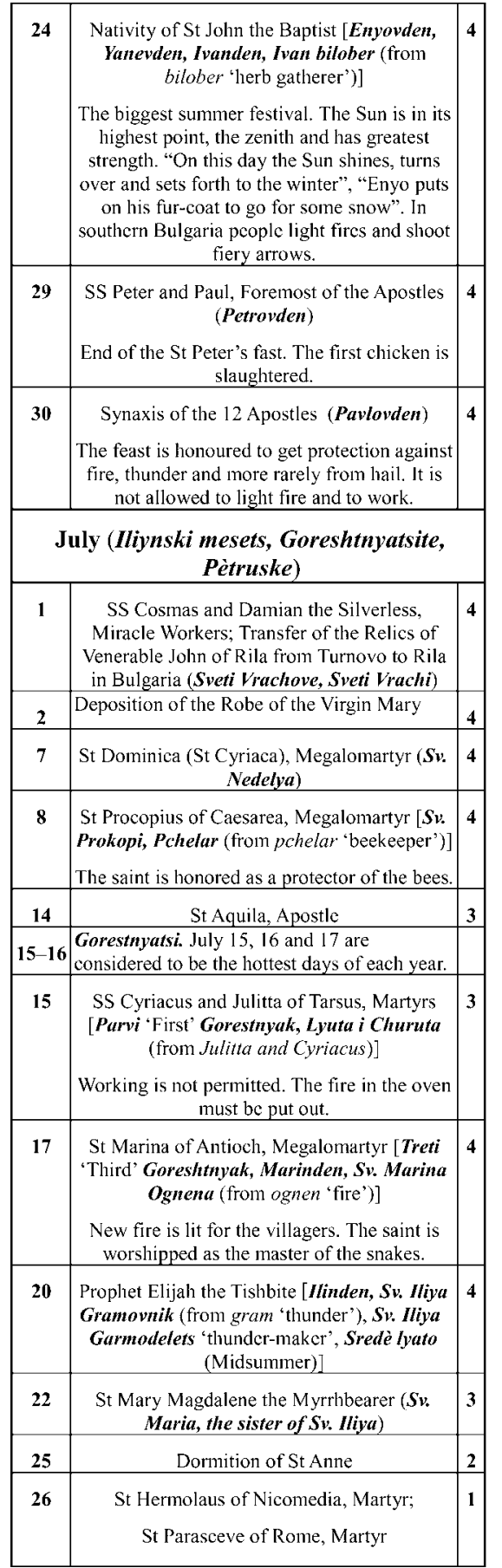

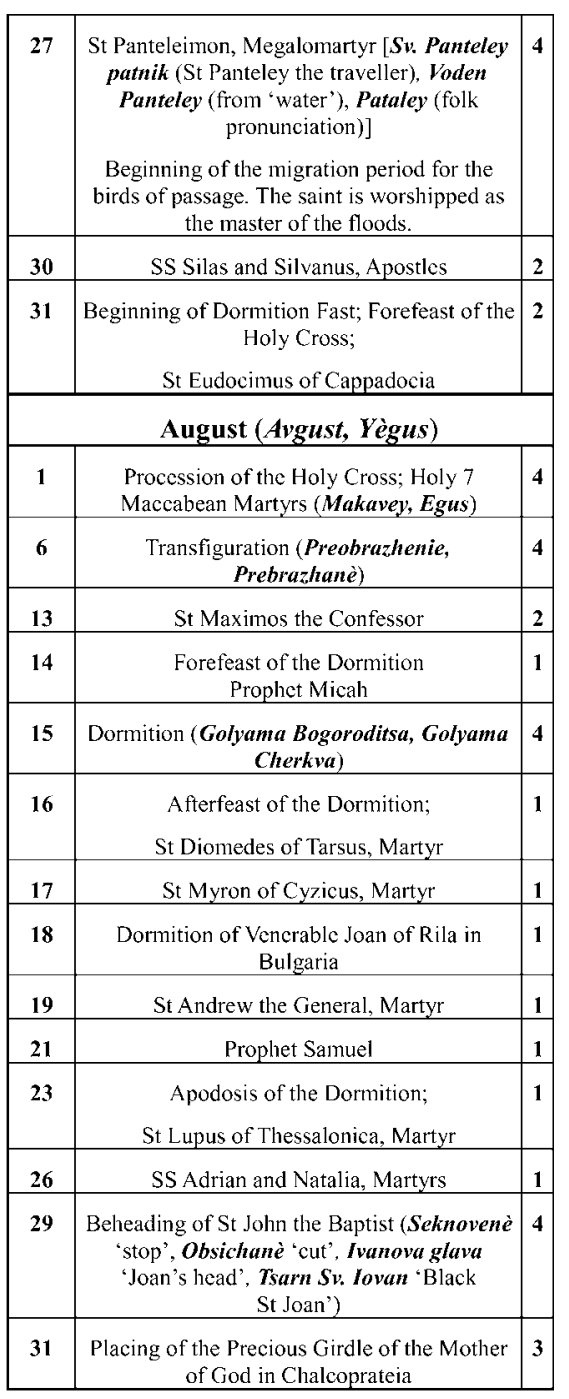




\section{ACKNOWLEDGEMENTS}

I am grateful to the specialists and collaborators at the Historical Museum in Bulgaria where wooden calendars were studied; to Antti Metsänkylä and Ildikó Lehtinen (National Museum of Finland) for their kind cooperation in studying the Finnish calendar collections; to Nikolay Sivkov (History Museum in Pernik, Bulgaria) for the information about the Komi calendars; Mare Kõiva and Andres Kuperjanov (Estonian Literary Museum in Tartu) for their kind help to acquaint me with the Estonian wooden calendars. The article is one of the results of a joint research project with the National Board of Antiquities, Finland, granted by the Bulgarian and Finnish Academy of Sciences.

\section{REFERENCES}

Anastasov, Vasil; Deikova, Hristina; Dimitrova-Todorova, Liliana; Dukova, Ute; Mikhailova, Dimitrina; Nacheva, Mira; Racheva, Mariia; Rikov, Georgi; Selimski, Liudvig \& Todorov, Todor At. 2002. Balgarski etimologichen rechnik, Tom VI. [Bulgarian Etymological Dictionary, Vol. 6] Sofia:Akademichno izdatelstvo "Marin Drinov", pp. 136-137.

Argirov, Stoyan 1896. Kalendar rabosh. [Calendar Rabosh.] Periodichesko spisanie na Balgarskoto knizhovno druzhestvo, Vol. 10, No. 54, pp. 779-785.

Dechov, Vasil 1903. Ovcharska godina i broenie. [Shepherds'Year and Count.] In: Sbornik za narodni umotvoreniya, Vol. 19. Sofia: Srednorodopsko ovcharstvo.

Detev, Petar 1947. Edin kalendar-rabosh v Plovdivskia naroden muzei. [A CalendarRabosh in the Plovdiv National Museum.] Balgarski narod, Vol. 2, No. 1. Sofia: Balgarsko narodonauchno druzhestvo, pp. 10-13.

Donchev, Slavi 1971. Pismenostta na prabalgarite i slavianskata azbuka. [The ProtoBulgarian Writing and the Slavic Alphabet.] Istoricheski pregled, Vol. 2, pp. 96109.

Doncheva-Petkova, Ludmila 1980. Znaci varhu arheologicheski pametnici ot Srednovekovna Balgaria, VII-X vek. [Signs on Archaeological Monuments from Medieval Bulgaria, 7th-10th Century.] Sofia: Izd. na Balg. Akad. na Naukite.

Gavazzi, Milovan 1938. Drveni kalendari. [Wooden calendars.] In: Kalendar Sv. Ante za g. 1939. Sarajevo, pp. 1-4.

Gorov, Goro 1997. Strandzhanskiyat vechen naroden kalendar - "pop”. [The Strandzha Mountain Eternal Folk Calendar - "Priest".] More, Vols. 9-10, pp. 9-11.

Koleva, Elena 1967. Naroden kalendar-rabosh ot 1783 godina. [Folk Calendar-Rabosh from the Year 1783]. Muzei i pametnici na kulturata, No. 1. Sofia, pp. 20-23.

Koleva, Elena 1971. Narodni kalendari-raboshi. [Folk Calendars-Rabosh.] Izvestiia na balgarskite muzei, Vol. 1 (1969), pp. 247-270.

Koleva, Svetlana \& Koleva, Vesselina 2006. The Finnish Wooden Calendars and Some Aspects of Folk Knowledge in the Middle Ages. In: A. Soltysiak (ed.). Proceedings of the Conference "Time and Astronomy in the Past Cultures", Torun, March 30April 1, 2005. Warszawa \& Toruń, pp. 149-166. 
Koleva, Vesselina 1996. Three Wooden Calendars from West Bulgaria. In: W. Schlosser (ed.) Proceedings of the Second SEAC Conference, Bochum, 1994, pp. 163-173.

Koleva, Vesselina 2006. Balgarskite darveni kalendari. [The Bulgarian wooden calendars.] Sbornik s dokladi ot Iubileina nauchna konferentsiia s mezhdunarodno uchastie "20 godini Saiuz na uchenite v Balgariia - klon Smolian”, 20-21 oktomvri, 2006, Smolyan, pp. 829-843.

Koleva, Vesselina 2007. Wooden Calendars from Southeastern Bulgaria. In: E. Pasztor (ed.) Papers from the annual meeting of SEAC held in Kecskemet, Hungary in 2004. BAR International Series S1647, pp. 95-107.

Koleva, Vesselina 2008. Wooden Calendars from the Central Rhodopes. Publications of the Astronomical Observatory of Belgrade, No. 85, pp. 65-86.

Koleva, Vesselina \& Georgiev, Ilia 2006. A Wooden Calendar from Southeastern Bulgaria. Aerospace Research in Bulgaria. Proceedings of the Balkan Astronomical Meeting, 2004, June 14-18, Rozhen, Bulgaria. Vol. 20, pp. 341-346.

Lipin, Vladimir 2006. Dereviannye reznye kalendary-sviacy v sobranii Nacionalnogo muzeia Respubliki Komi. [Wooden Notched Calendars in the Collection of the National Museum of the Komi Republic.] Art, Vol. 3. Syktyvkar, pp. 120-128.

Manolova, Maria 1980. Rodopskite rodovi damgi - prabalgarski pismeni znaci. [The Rhodopean family damga signs - Proto-Bulgarian writing signs.] Rhodopi, Vol. 10, pp. 7, 24-26.

Marinov, Dimitar 1907. Paterica. [Crutch.] Izvestiia na Etnograficheskiia muzei, Year I, pp. 11-14.

Marinov, Dimitar 1914. Narodna vyara i religiozni narodni obichai [Popular Belief and Religious Folk Customs]. Sbornik za narodni umotvoreniia, Vol. 8, pp. $269 \mathrm{ff}$.

Mladenov, Stefan 1941. Etimologicheski i pravopisen rechnik na balgarskiia knizhoven ezik. [Etymological Dictionary and Orthography of the Bulgarian Literary Language.] Sofia: Knigoizdatelstvo "Hristo G. Danov" - O.O. D-vo.

Savvaitov, Pavel Ivanovich 1869. O sirianskikh dereviannykh kalendariakh i permskoi azbuke, izbretennoi Sv. Stefanom. [About Zyryan Wooden Calendars and the Permian Alphabet Invented by St Stefan.] Trudy pervogo arkheologicheskogo sezda, pp. 408-416.

Sefterski, Raiko 2001. Drevni pismeni znatsi varhu balgarski darveni kalendari ot XVIII-XX vek (sapostavitelno izsledvane). [Ancient Letters on Bulgarian Wooden Calendars from 18th-20th Centuries (A Comparative Study).] Izvestiia na Balgarskata orda, Year 7, No. 2 (62), pp. 2-15.

Sergius of Valaam. Wikipedia. Retrieved on 1 Feb, 2010, from http://en.wikipedia.org/ wiki/Sergius_of_Valaam.

Sreznevskii, Vsevolod Izmailovich 1876. Severnyi reznoi kalendar'. [Nordic notched Calendar.] In: Trudy vtorogo arkheologicheskogo s'ezda v Sankt Peterburge, Vyp. 1-2, pp. 1-108.

Stipa, Günter Johannes 1966. Zum Kulturbereich der syrjänischen Kerbkalender. Finnisch-Ugrische Forschungen, Band XXXVI, Heft 1-2, pp. 181-207.

Vakarelski, Hristo 1936. Kalendar. [Calendar.] Bit u ezik na trakiiskite i maloaziiski balgari. Sofia: Bit, Duhovna kultura. Part 1, pp. 269-273.

Zakhariev, Iordan 1929. Kalendar-rabosh. [Calendar-Rabosh.] Izvestie na Narodniia etnografski muzei v Sofia, Vol. 8-9, pp. 242-248. 